\title{
Conf-950412--35
}

UCRL-JC-118964

PREPRINT

\section{Measuring Enthalpies of Formation Using Thick Multilayer Foils and Differential Scanning Calorimetry}

T. P. Weihs

T. W. Barbee, Jr.

M. A. Wall

This paper was prepared for presentation at MRS 1995 Spring Meeting, San Francisco, CA

April 17-21, 1995

April 14, 1995

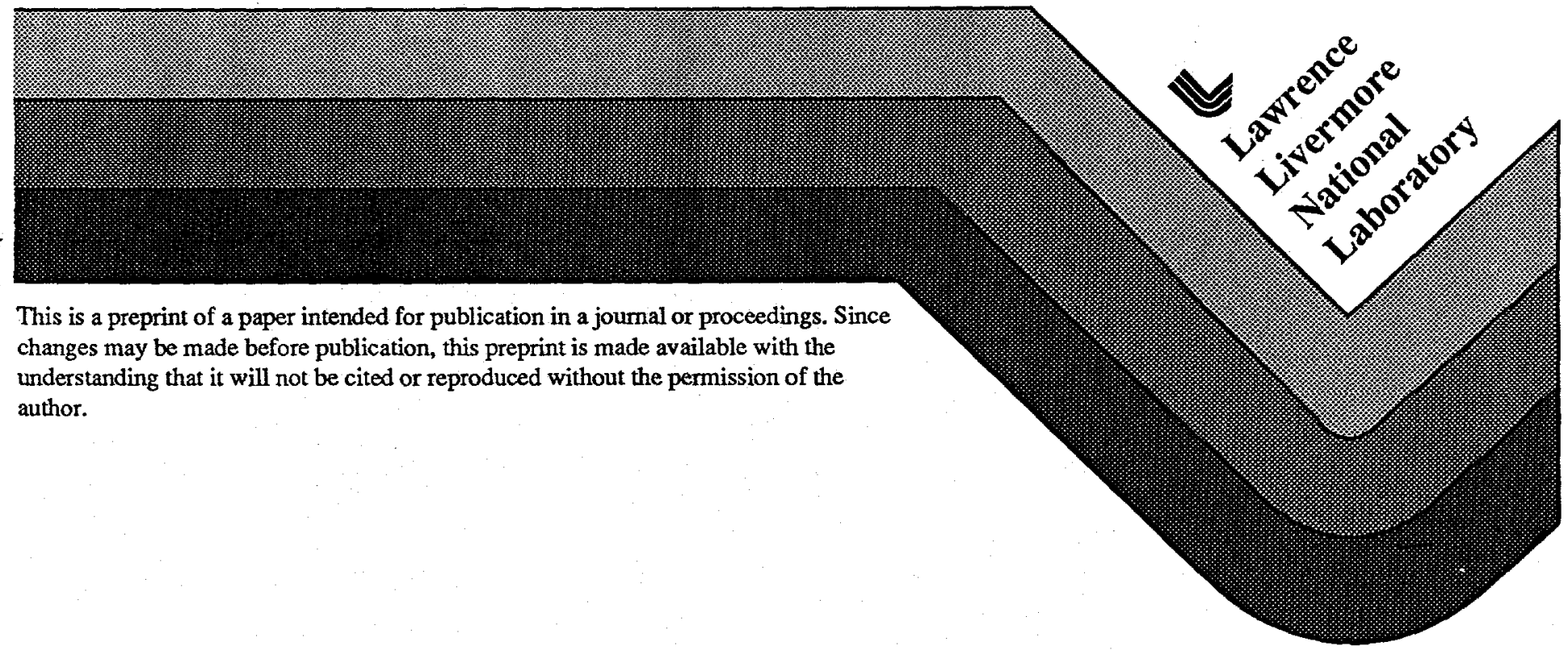




\section{DISCLAIMER}

Portions of this document may be illegible in electronic image products. Images are produced from the best available original document. 


\title{
MEASURING ENTHALPIES OF FORMATION USING THICK MULTILAYER FOILS AND DIFFERENTIAL SCANNING CALORIMETRY
}

\begin{abstract}
T.P.Weihs, T.W. Barbee, Jr., and M.A. Wall, Lawrence Livermore National Laboratory, Livermore, CA 94551.
\end{abstract}

\section{ABSTRACT}

The ability to measure formation enthalpies of compounds at relatively low temperatures using thick multilayer foils and differential scanning calorimetry is demonstrated. $\mathrm{Cu} / \mathrm{Zr}$ and $\mathrm{Al} / \mathrm{Zr}$ multilayers were deposited onto $\mathrm{Si}$ and glass substrates using a planetary, magnetron source sputtering system. The as-deposited foils were removed from their substrates and heated from $50^{\circ} \mathrm{C}$ to $725^{\circ} \mathrm{C}$ in a differential scanning calorimeter (DSC). The $\mathrm{Cu} / \mathrm{Zr}$ samples, which are all $\mathrm{Cu}-$ rich, showed three distinct, reproducible, and exothermic solid state reactions. The heats from the first two reactions were summed and analyzed to measure $14.3 \pm 0.3 \mathrm{~kJ} / \mathrm{mol}$ for $\mathrm{Cu}_{51} \mathrm{Zr}_{14}$ 's enthalpy of formation. This quantity agrees with the single value of $\Delta \mathrm{H}_{\mathrm{f}}=14.07 \pm 1.07 \mathrm{~kJ} / \mathrm{mol}$ reported for this compound. The composition of the $\mathrm{Al} / \mathrm{Zr}$ multilayers ranged from 8 at $\% \mathrm{Zr}$ to 64 at\% $\mathrm{Zr}$. These samples showed a variety of distinct, reproducible, and exothermic solid state reactions. The total heats from these reactions were summed and analyzed to measure enthalpies of formation for five different $\mathrm{Al}-\mathrm{Zr}$ alloys. The results compare favorably with literature values of $\Delta \mathrm{H}_{\mathrm{f}}$. Advantages of measuring enthalpies of formation using thick multilayer foil samples and low temperature DSC calorimetry are discussed.

\section{INTRODUCTION}

Multilayer materials with nano-scale layering can react in the solid state at very low temperatures, often well below the melting temperatures of the individual layers $[1,2]$. The small dimensions of the layering provide short diffusion distances that greatly enhance elemental mixing compared to bulk materials. New phases and compounds can form readily, and large heats of reactions can be produced. Solid state reactions (SSRs) have already been studied in a wide variety of multilayer systems using commercial Differential Scanning Calorimeters (DSC) that operate below $800^{\circ} \mathrm{C}[1,3,4]$. By carefully designing a set of multilayer samples, and by carefully analyzing the exothermic heats from these SSRs, enthalpies of formation $\left(\Delta \mathrm{H}_{f}\right)$ can be measured accurately at low temperatures $\left(<800^{\circ} \mathrm{C}\right)$.

Measuring $\Delta \mathrm{H}_{\mathrm{f}}$ at low temperatures using solid state reactions greatly reduces the risk of environmental contamination compared to high temperature reaction calorimetry [5-6]. This is particularly useful for transition metal compounds that contain reactive materials such as $\mathrm{Ti}, \mathrm{Zr}$ and Hf. This paper reports measurements of $\Delta \mathrm{H}_{\mathrm{f}}$ for one $\mathrm{Cu}-\mathrm{Zr}$ compound and five $\mathrm{Al}-\mathrm{Zr}$ alloys to demonstrate the ability to accurately measurement enthalpies of formation at low temperatures using multilayer foils and DSC. A series of thick multilayer foils were fabricated for each compound or alloy using a planetary magnetron sputtering system. The foils were heated in a DSC and the resulting exothermic heat flows were analyzed using a simple model to account for interfacial reactions that occur during sample fabrication. The resulting values agree with the available literature.

\section{EXPERIMENTAL PROCEDURES}

Multilayer samples were fabricated by magnetron sputter depositing $\mathrm{Cu}$ and $\mathrm{Zr}$ onto 3 in and 6in (100) Si wafers and $\mathrm{Al}$ and $\mathrm{Zr}$ onto 27 in glass substrates using a planetary system [7]. The purities of the $\mathrm{Cu}, \mathrm{Zr}$, and $\mathrm{Al}$ targets were $99.999 \%, 99.95 \%, 99.5 \%$, respectively. The multilayer samples were 25 to $50 \mu \mathrm{m}$ thick, and they were easily removed from the substrates as free standing foils. The $\mathrm{Cu} / \mathrm{Zr}$ samples are limited to $\mathrm{Cu}$-rich compositions $(0.9$ to 12.3 at\% $\mathrm{Zr})$ while the $\mathrm{Al} / \mathrm{Zr}$ samples cover a broader range from 8 at $\mathrm{Zr}$ to 66 at\% $\mathrm{Zr}$. Compositions of all samples were predicted using calibrated deposition parameters. The composition of most samples were also measured using a combination of wet chemistry and X-ray Fluorescence (XRF) [8]. In almost all cases the predicted compositions fell within the experimental uncertainty $( \pm 5 \%)$ of the measured compositions. Because the $\mathrm{Cu} / \mathrm{Zr}$ multilayers were deposited on to small substrates, the $\mathrm{Cu}$ and $\mathrm{Zr}$ 
layer thicknesses were relatively uniform across the foils and only one layer thickness was tested for each sample. The $\mathrm{Al} / \mathrm{Zr}$ multilayers were deposited on much larger substrates and large variations $(>3 x)$ in layer thicknesses developed across the complete foil. Thus, several different layer thicknesses were tested for each $\mathrm{Al} / \mathrm{Zr}$ multilayer sample. The composition was assumed constant across a given foil.

The $\mathrm{Cu} / \mathrm{Zr}$ and $\mathrm{Al} / \mathrm{Zr}$ multilayers are predominantly crystalline after deposition as shown in Figure 1. The individual layers are highly textured with $\mathrm{Cu}(111), \mathrm{Zr}(002)$ and $\mathrm{Al}(111)$ planes lying parallel to the foil's layering. The $\mathrm{Cu}$ and the $\mathrm{Zr}$ grains scale in size with their layer thickness while the $\mathrm{Al}$ grains tend to be $2 \mathrm{x}$ wider than their layer thickness. Thin, reaction layers of amorphous $\mathrm{Cu}-\mathrm{Zr}$ and $\mathrm{Al}-\mathrm{Zr}$ could be seen in as-deposited samples using high-resolution, crosssectional TEM. This demonstrates that some fraction of the solid state reactions (SSRs) begins during the synthesis of the materials.

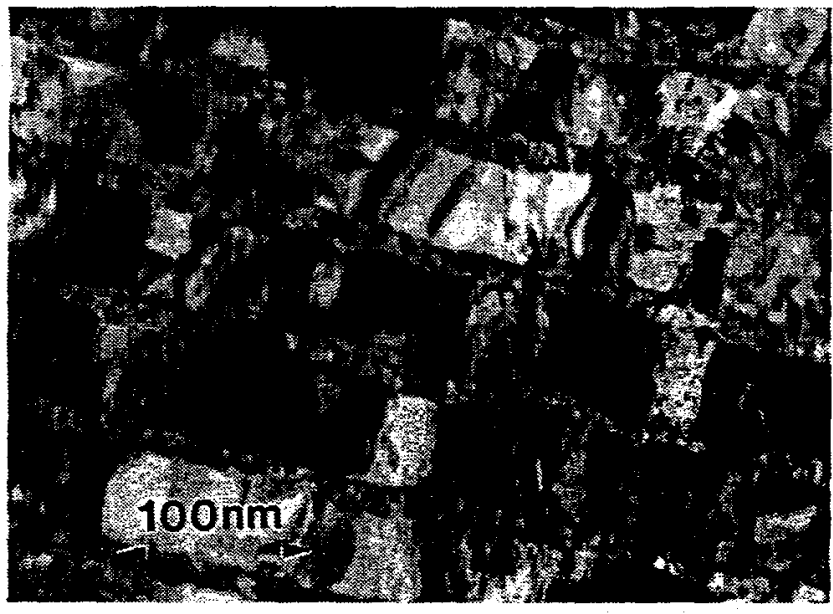

(a)

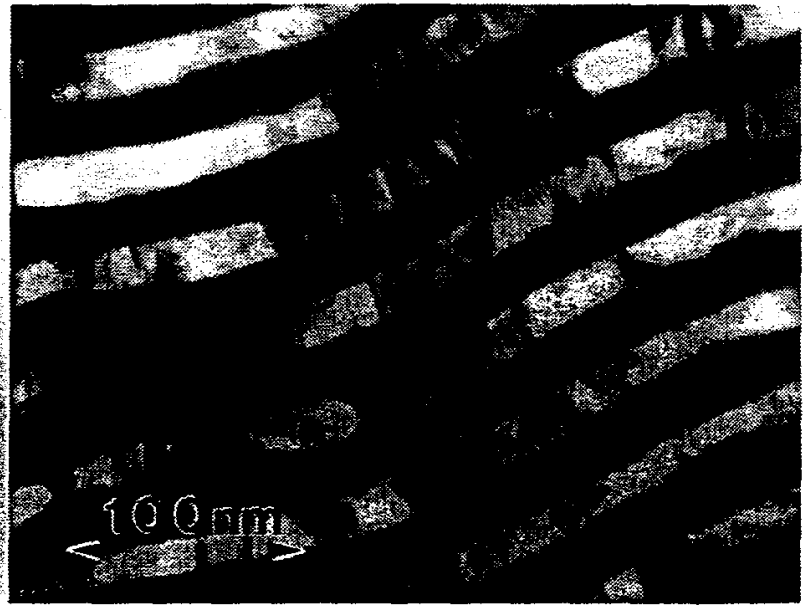

(b)

Figure 1: TEM images of as-deposited layers of polycrystalline (a) $\mathrm{Cu}$ and $\mathrm{Zr}$ and (b) $\mathrm{Al}$ and $\mathrm{Zr}$.

Differential scanning calorimetry was used to determine the heats of transformations in the $\mathrm{Cu} / \mathrm{Zr}$ and $\mathrm{Al} / \mathrm{Zr}$ multilayer foils. Disks were punched from the multilayer foils, crimped flat in $\mathrm{Cu}$ pans, and then isochronally scanned from $50^{\circ} \mathrm{C}$ to $725^{\circ} \mathrm{C}$ at heating rates that ranged from $25^{\circ} \mathrm{C}$ to $100^{\circ} \mathrm{C} / \mathrm{min}$. The specimens were heated in high purity Ar to minimize oxidation Each sample was scanned to $725^{\circ} \mathrm{C}$ twice to provide a baseline for subtraction. The net heat flows were integrated with respect to time to determine the heats (Q) of the exothermic reactions. The amorphous and crystalline phases that formed were identified using $\mathrm{x}$-ray diffraction (XRD) and transmission electron microscopy (TEM). For these structural analyses, specimens were isochronally scanned to a fixed temperature and then quenched.

\section{MODEL}

The amount of heat that is lost when SSRs begin during deposition can be modeled using a simple geometrical argument. Consider a multilayer that consists of alternate layers of materials A and $B$. Assume that material $A$ is the first layer to be consumed by the SSRs when the samples are heated. Furthermore, assume that $t_{r x}$ is the thickness of $A$ that reacts at each $A / B$ interface during deposition. $t_{0}$ is assumed to be the thickness of $A$ that would be deposited if no reaction occurred. $2\left(\mathrm{t}_{\mathrm{IX}} / \mathrm{t}_{0}\right)$ is then the volume fraction of $\mathrm{A}$ that reacts during deposition. The heat that is lost due to this reaction is equal to $2 \mathrm{f} \Delta \mathrm{H}_{\mathrm{f}}\left(\mathrm{t}_{\mathrm{rx}} / \mathrm{t}_{0}\right)$ where $\Delta \mathrm{H}_{\mathrm{f}}$ is the enthalpy of formation of the final phase to be measured, and $f \Delta H_{f}$ is the enthalpy of formation of the first phase that appears. $f$ is simply a fraction less than one that relates the two enthalpies. If the deposition conditions are similar for a given set of samples, then $t_{\mathrm{rx}}$ should be equal for all samples in that set. The molar heat $(\mathrm{Q})$ for the SSRs will then vary as,

$\mathrm{Q}=\Delta \mathrm{H}_{\mathrm{f}}\left[1-2 \mathrm{f}\left(\mathrm{t}_{\mathrm{rx}} / \mathrm{t}_{0}\right)\right]$ 
Plotting $Q$ versus the reciprocal of to enables $\Delta \mathrm{H}_{\mathrm{f}}$ to be determined from the intercept at $1 / t_{0}=0$. At $1 / t_{0}=0$, the layers of the sample are infinitely thick; the heat losses during deposition are negligible; and $\mathrm{Q}$ yields $\Delta \mathrm{H}_{\mathrm{f}}$ directly.

When the multilayer period, $d$, is known more accurately than the layer thickness, it is advantageous to use $d$ in place of $t_{0}$. This can be done when a sample has a fixed composition but a varying multilayer period. In this case, the multilayer period will scale directly with layer thickness. Thus, $\mathrm{d}$ can be used in place of $t_{0}$ in Equation (1) with the addition of a constant. This was done for the $\mathrm{Al} / \mathrm{Zr}$ system. However, the multilayer period can not be used in place of layer thickness when the composition and the ratio of layer thicknesses vary from sample to sample. This is true for the $\mathrm{Cu} / \mathrm{Zr}$ system.

\section{RESULTS AND DISCUSSION}

$\underline{\mathrm{Cu} / \mathrm{Zr} \text { Multilayers: }}$

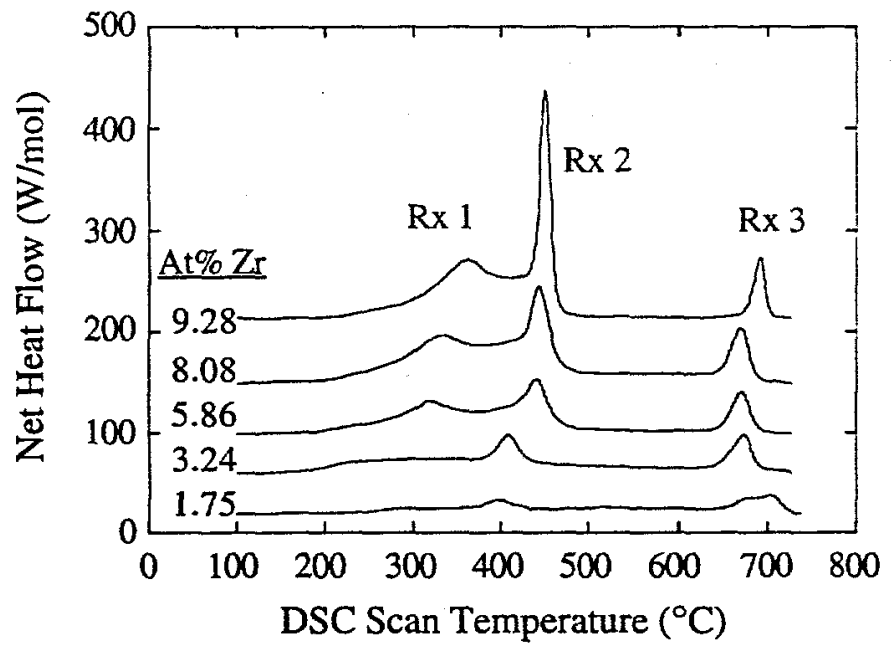

Figure 2: Net heat flows from isochronal DSC scans of $\mathrm{Cu} / \mathrm{Zr}$ Multilayer Samples. The heating rate was $100^{\circ} \mathrm{C} / \mathrm{min}$.

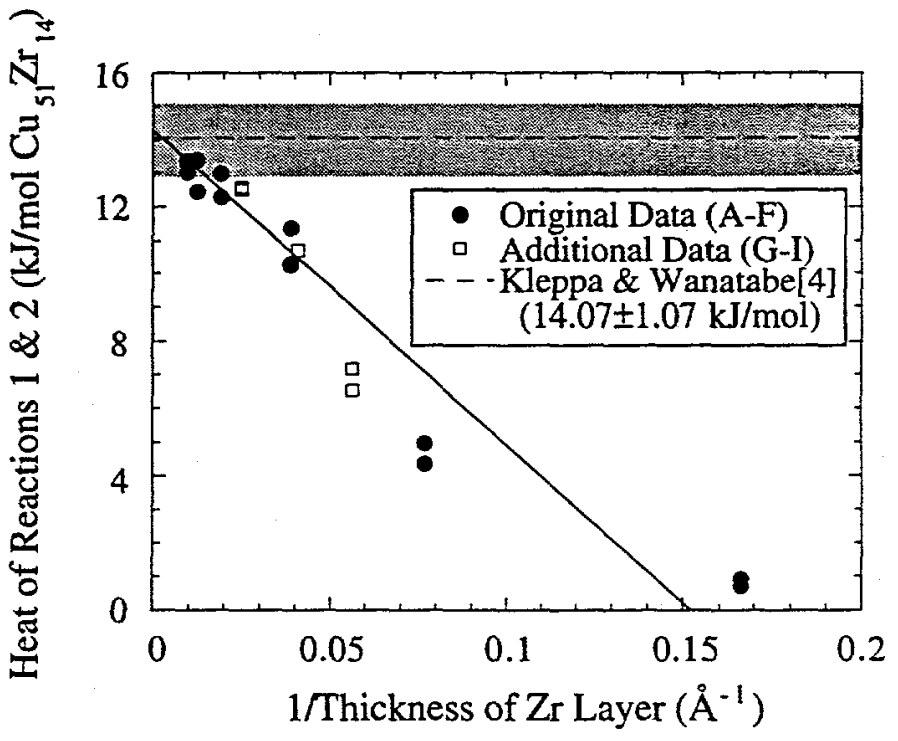

Figure 3: Heats of $\mathrm{Rx} 1$ and $\mathrm{Rx} 2$ for $\mathrm{Cu} / \mathrm{Zr}$ multilayer samples. Heats are calculated per mole of $\mathrm{Cu}_{51} \mathrm{Zr}_{14}$
Three distinct exotherms were observed when the $\mathrm{Cu} / \mathrm{Zr}$ samples were heated to $725^{\circ} \mathrm{C}$, and the net heat flows for these reactions are shown in Figure 2. The heat flows were very reproducible for a given sample. XRD and TEM data [11] showed that the broad, initial exotherm can be attributed to the formation of an amorphous $\mathrm{Cu}-\mathrm{Zr}$ alloy; the second exotherm can be attributed to the formation of the crystalline phase, $\mathrm{Cu}_{51} \mathrm{Zr}_{14}$; and the third exotherm can be attributed to the transformation of $\mathrm{Cu}_{51} \mathrm{Zr}_{14}$ to $\mathrm{Cu}_{9} \mathrm{Zr}_{2}$ and interface/grain boundary energies [11]. The three exothermic reactions are labeled $\mathrm{Rx}$ $1, \mathrm{Rx} 2$ and $\mathrm{Rx} 3$, and they were observed for all $\mathrm{Cu}-\mathrm{Zr}$ samples except those with the thinnest $\mathrm{Zr}$ layers. Since the reactants and products for $\mathrm{Rx} 1$ and $\mathrm{Rx} 2$ are alternating layers of $\mathrm{Cu}$ and $\mathrm{Zr}$, and $\mathrm{Cu}$ and $\mathrm{Cu}_{51} \mathrm{Zr}_{14}$, respectively, the combined heat for $\mathrm{Rx} 1$ and $\mathrm{Rx} 2$ is the heat released by the formation of $\mathrm{Cu}_{51} \mathrm{Zr}_{14}$. The heat for both reactions, $Q_{1}+Q_{2}$, was calculated based on the number of moles of $\mathrm{Cu}_{51} \mathrm{Zr}_{14}$ that formed in each sample, and the resulting values are plotted in Figure 3 versus the reciprocal of the $\mathrm{Zr}$ layer thickness.

The heats of $\mathrm{Rx} 1$ and $\mathrm{Rx} 2$ for all of the $\mathrm{Cu}-\mathrm{Zr}$ samples follow the same linear relationship in Figure 3. Using the linear fit, Equation (1), the value of $Q_{1}+Q_{2}$ 
at $1 / \mathrm{Zzr}_{\mathrm{r}}=0$, and the scatter in the linear fit, $\Delta \mathrm{H}_{\mathrm{f}}$ was calculated to be $14.3 \pm 0.3 \mathrm{~kJ} / \mathrm{mol}$ for $\mathrm{Cu}_{51} \mathrm{Zr}_{14}$. This value is very close to Kleppa and Wanatabe's[12] careful measurement of $14.07 \pm 1.24 \mathrm{~kJ} / \mathrm{mol}$, and it falls well within their scatter band. Note that the uncertainty in the enthalpy measured here is only $0.3 \mathrm{~kJ} / \mathrm{mol}$ or $2.1 \%$. This small uncertainty in $\Delta \mathrm{H}_{\mathrm{f}}$, and the agreement between it and Kleppa and Wanatabe's value, demonstrate that enthalpies of formation of metallic alloys can be measured in a relatively simple and accurate manner using low temperature calorimetry and multilayer foils.

\section{Al/Zr Multilayers:}

Net heat flows from DSC scans of each of the five $\mathrm{Al} / \mathrm{Zr}$ samples are plotted in Figure 4. The composition of the five samples are listed on the left side of the Figure 4 in at $\mathrm{Zr}$. The products of the exothermic SSRs were determined using XRD, and they are listed on the right hand side of the Figure 4 and in Table 1. The stable compounds [13] were obtained for all samples except the one with 46.8 at\% $\mathrm{Zr}$.

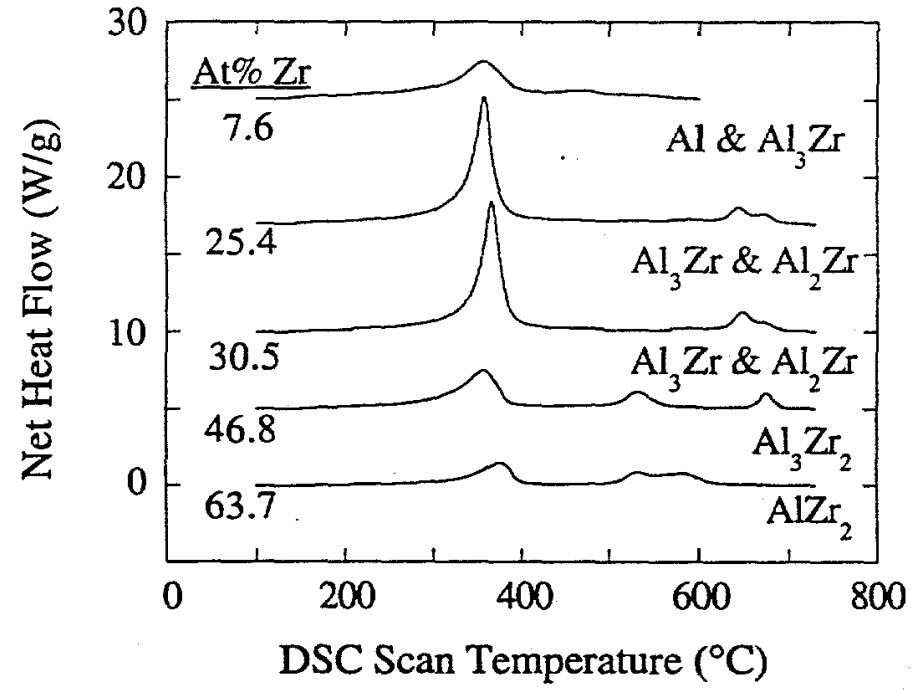

Figure 4: Net heat flows from isochronal DSC scans of Al/ $\mathrm{Zr}$ Multilayer Samples. The heating rate was $25^{\circ} \mathrm{C} / \mathrm{min}$. The final products are listed to the right for each scan.
The sample with only 7.6 at\% $\mathrm{Zr}$ showed one major and two minor exotherms which produced $\mathrm{Al}$ and the stable, tetragonal form of $\mathrm{Al}_{3} \mathrm{Zr}$. The endotherm due to $\mathrm{Al}$ melting at $660^{\circ} \mathrm{C}$ was removed from the DSC scan in Figure 4. The next two samples (25.4 and 30.5 at\% $\mathrm{Zr}$ ) each have one major exotherm at $350^{\circ} \mathrm{C}$ followed by one or two smaller exotherms at higher temperatures. The products of these SSRs are the stable compounds tetragonal $\mathrm{Al}_{3} \mathrm{Zr}$ and hexagonal $\mathrm{Al}_{2} \mathrm{Zr}$ for both samples. However, the sample with only 25.4 at\% $\mathrm{Zr}$ has weak $\mathrm{Al}_{2} \mathrm{Zr}$ peaks suggesting little of this phase is present, as expected. The sample with 46.8 at\% $\mathrm{Zr}$ had three exothermic reactions but did not yield the stable compound AlZr. $\mathrm{Al}_{3} \mathrm{Zr}_{2}$, which is also stable for the composition, was clearly present in the reacted samples, and there was some evidence of $\mathrm{Al}_{3} \mathrm{Zr}_{4}$. But, the XRD peaks were too weak to confirm this phase. Since the formation of $\mathrm{AlZr}$ was expected for this sample, other specimens were heated in a differential thermal analyzer (DTA) to $1350^{\circ} \mathrm{C}$. The DTA scan produced two additional exotherms at $860^{\circ}$ and $1200^{\circ} \mathrm{C}$. While the heat flows were not calibrated for this instrument, the two additional exotherms are roughly estimated to increased the total exothermic heat for the sample by $29 \%$. The last sample with 63.7 at\% $\mathrm{Zr}$ produced three exothermic reactions upon heating to $725^{\circ} \mathrm{C}$. The final product was predominantly $\mathrm{AlZr}_{2}$. Some $\mathrm{Al}_{3} \mathrm{Zr}_{2}$ may also be present, as expected, but the peaks were too weak to verify its existence.

\begin{tabular}{|c|c|c|c|c|}
\hline Sample & Composition & \multicolumn{2}{|c|}{ Products of Reactions } & $\Delta \mathbf{H}_{f}$ \\
\hline & (at\% $\mathrm{Zr}$ ) & (Expected) & (Obtained) & $(\mathrm{kJ} / \mathrm{mol})$ \\
1 & & & & \\
2 & 7.6 & $\mathrm{Al} \& \mathrm{Al}_{3} \mathrm{Zr}$ & $\mathrm{Al} \& \mathrm{Al}_{3} \mathrm{Zr}$ & $16.6 \pm 0.7$ \\
3 & 25.4 & $\mathrm{Al}_{3} \mathrm{Zr} \& \mathrm{Al}_{2} \mathrm{Zr}$ & $\mathrm{Al}_{3} \mathrm{Zr} \& \mathrm{Al}_{2} \mathrm{Zr}$ & $46.5 \pm 3.5$ \\
4 & 30.5 & $\mathrm{Al}_{3} \mathrm{Zr} \& \mathrm{Al}_{2} \mathrm{Zr}$ & $\mathrm{Al}_{3} \mathrm{Zr} \& \mathrm{Al}_{2} \mathrm{Zr}$ & $51.4 \pm 3.6$ \\
5 & 46.8 & $\mathrm{AlZr}_{3} \mathrm{Al}_{3} \mathrm{Zr}_{2}$ & $\mathrm{Al}_{3} \mathrm{Zr}_{2}$ & $52.1 \pm 0.9$ \\
\hline
\end{tabular}

$* \Delta \mathrm{H}_{\mathrm{f}}$ is estimated based on DSC and DTA data for this sample. 
The temperatures and sizes of the exotherms in Figure 4 varied as the multilayer period was decreased for a given sample. However, the DSC scans were reproducible for any given sample and any given thickness. The net heat flows were integrated to obtain a total heat of the SSRs, Q, and these heats were plotted versus the reciprocal of the multilayer period, $d$. A line was fit to the data as shown in Figure 3, and it was extrapolated to $1 / d=0$ to obtain enthalpies of formation for each of the samples using Equation (1). These results are listed in Table 1 and they are plotted in Figure 5 along with other values from the literature.

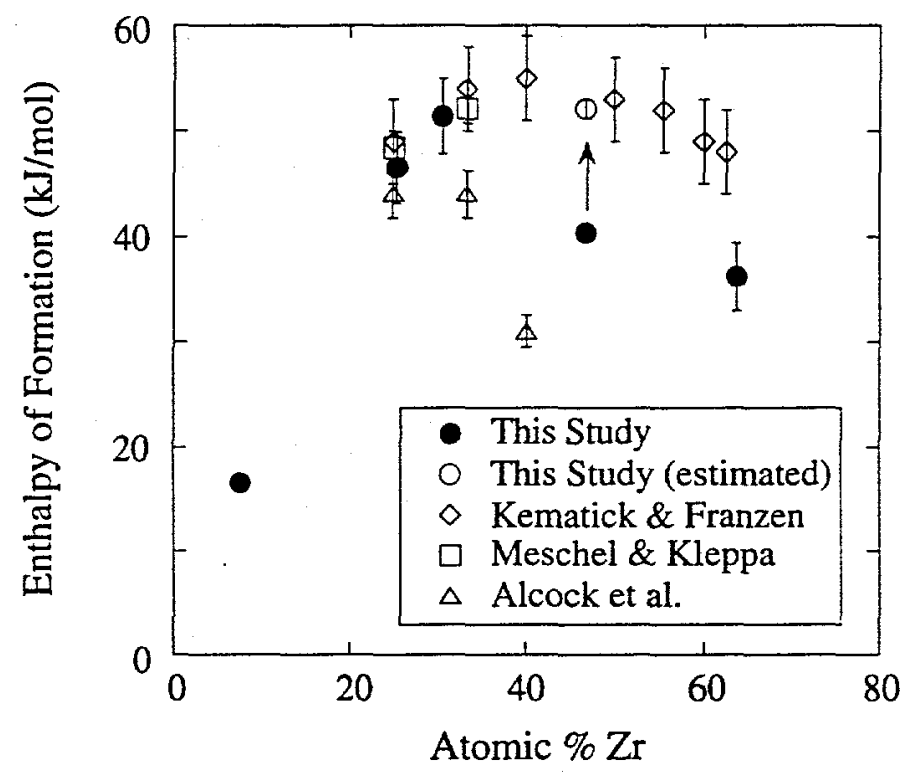

Figure 5: Enthalpies of formation for $\mathrm{Al} / \mathrm{Zr}$ multilayer samples. $\Delta \mathrm{H}_{\mathrm{f}}$ for the sample with 46.8 at\% $\mathrm{Zr}$ is estimated to be $29 \%$ higher or $52.1 \mathrm{~kJ} / \mathrm{mol}$.
The enthalpies of formation obtained from DSC of multilayer foils agree with most of the available literature, particularly on the Al-rich end of the Al-Zr system. Kematick and Franzen produced a large set of $\Delta \mathrm{H}_{\mathrm{f}}$ data using a Knudsen cell mass spectrometric technique to measure $\mathrm{Al}$ vapor pressures between $1025^{\circ} \mathrm{C}$ and $1400^{\circ} \mathrm{C}$. The values plotted in Figure 5 were corrected by Murray, Peruzzi, and Abriata. Meschel and Kleppa used $\mathrm{Al}$ and $\mathrm{Zr}$ powders and direct synthesis calorimetry to measure $\Delta \mathrm{H}_{\mathrm{f}}$ for $\mathrm{Al}_{3} \mathrm{Zr}$ and $\mathrm{Al}_{2} \mathrm{Zr}$. Values from both of these references agree very closely with the enthalpies measured here for samples 1,2 and 3 . The estimate for Sample $4(46.8$ at\% $\mathrm{Zr})$ also agrees with Kematick and Franzen's data. The only major discrepancy with literature values is for Sample 5 with 63.7 at\% $\mathrm{Zr}$. Since reflections from the expected phase, $\mathrm{AlZr}_{2}$, were observed in XRD scans, the authors are confident that the heats of the SSRs yield an accurate measure for $\Delta \mathrm{H}_{\mathrm{f}}$ for this alloy.

\section{Cautions and Comments}

Nano-scale multilayers contain a very high density of interfaces which can store considerable amounts of energy. The contribution of interface energy in $\mathrm{Rx} 3$ for the $\mathrm{Cu}-\mathrm{Zr}$ system (Figure 2) was determined to be as high as $4 \mathrm{~kJ} / \mathrm{mol}$ for the samples with very thin $\mathrm{Zr}$ layers[11]. Thus, interface energy and structural stability must be considered when measuring $\Delta \mathrm{H}_{\mathrm{f}}$ in samples with layers thinner than $100 \AA$. The model presented above accounts for interfacial energy effects indirectly by extrapolating to infinitely thick layers to determine $\Delta \mathrm{H}_{\mathrm{f}}$. When $1 / t_{0}=0$, the contribution of interfacial energy to measured heats will be zero.

Measuring enthalpies of formation using thick, multilayer samples and differential scanning calorimetry has two distinct advantages over conventional high temperature calorimetry. First, the nano-scale layering of the multilayer foils provides shorter diffusion distances and therefore lower reaction temperatures than the 10-50 $\mu \mathrm{m}$ diameter powders that are typically used in direct reaction calorimetry. The lower reaction temperatures reduce the risk of contamination and permit the use of commercial calorimeters for measuring heats of reactions. The samples tested here showed inconsequential amounts of surface oxidization during the DSC measurements. Second, the heats of formation of several different phases can be compared using a single sample. For the $\mathrm{Cu} / \mathrm{Zr}$ multilayers, three $\mathrm{Cu}-\mathrm{Zr}$ phases were observed. The first is a metastable, amorphous $\mathrm{Cu}-\mathrm{Zr}$, the second is the metastable compound, $\mathrm{Cu}_{51} \mathrm{Zr}_{14}$, and the last is the stable compound, $\mathrm{Cu}_{9} \mathrm{Zr}_{2}$. Since all three phases form in distinct solid state reactions when the samples are heated(see Figure 2), their separate enthalpies of formation can be determined and compared using the heat flow data for a single specimen[12,13]. Such 
measurements can lead to direct comparisons of enthalpies of formation of different phases within an alloy system. This, in turn, will improve predictions of phase stability $[12,13]$. An additional strength of this technique is the sensitivity with which heat can be measured using $\mathrm{DSC}[17]$. Heats as small as $13 \mathrm{~mJ}$ were measured for individual reactions. With the average specimen weighing $20 \mathrm{mg}$ or more, reactions that emit as little as $1 \mathrm{~J} / \mathrm{g}$ can be quantified. On a per mole basis, this implies that enthalpies of formation as small as $0.5 \mathrm{~kJ} / \mathrm{mol}$ can be determined with this technique. Essentially all metallurgical systems can be studied with this sensitivity [3].

\section{CONCLUSIONS}

A technique to accurately measure formation enthalpies of transition metal compounds at relatively low temperatures using thick multilayer foils and differential scanning calorimetry has been demonstrated. $\mathrm{Cu} / \mathrm{Zr}$ and $\mathrm{Al} / \mathrm{Zr}$ multilayer foils were scanned in temperature up to $725^{\circ} \mathrm{C}$, and distinct exothermic reactions were consistently observed with minimal sample surface oxidization. The heats that evolved during the exothermic reactions were analyzed using a model that accounts for heat losses due to interfacial reactions during deposition. $14.3 \pm 0.3 \mathrm{~kJ} / \mathrm{mol}$ was measured for $\mathrm{Cu}_{51} \mathrm{Zr}_{14}$ 's enthalpy of formation. This formation enthalpy is within $2 \%$ of the single value of $\Delta \mathrm{H}_{\mathrm{f}}$ reported for this alloy. Enthalpies of formation equal to $16.6 \pm 0.7,46.5 \pm 3.5,51.4 \pm 3.6,52.1 \pm 0.9$, and $36.2 \pm 3.2 \mathrm{~kJ} / \mathrm{mol}$ were measured for five $\mathrm{Al} / \mathrm{Zr}$ alloys containing 7.6, 25.4, 30.5, 46.8, and 63.7 at $\mathrm{Zr}$, respectively. All of these measurements agree with literature values except for the $\mathrm{Zr}$ rich alloy. The close agreement between the measured values and the literature values for $\Delta \mathrm{H}_{\mathrm{f}}$, and the lack of environmental contamination of specimens, demonstrate that DSC of thick multilayer foils is an effective alternative to high temperature calorimetry for measuring enthalpies of formation of transition metal compounds.

\section{ACKNOWLEDGMENTS}

The authors wish to thank Jennifer Alameda and Barry Olsen for their technical assistance. This work was performed under the auspices of the U. S. Department of Energy by Lawrence Livermore National Laboratory under Contract No. W-7405-ENG-48.

\section{REFERENCES}

1) W.L. Johnson, Mater. Sci. and Eng., 97, 1 (1988).

2) Mat. Res. Soc. Proceedings, Vol 311, edited by M. Atzmon, A.L.Greer, J.M. Harper, and M.R. Liberia, Spring 1993.

3) L.A. Clevenger, C.V. Thompson, R.C. Cammarata, and K.N. Tu, Appl. Phys. Lett., 52 , 795 (1988).

4) R.J. Highmore, J.E. Evetts, A.L. Greer, and R.E. Somekh, Appl. Phys. Lett., 50, 566 (1987).

5) O.J. Kleppa, J. Phase Equil., 15, 240 (1994).

6) O. Kubaschewski and C.B. Alcock, Metallurgical Thermochemistry, Pergamon Press, NY, 1979.

7) T. W. Barbee, Jr., "Multilayer Synthesis by Physical Vapor Deposition" in Synthetic Modulated Structures, ed. by L. Chang and B. C. Giessen, (Academic Press, New York, 1985), pp. 313-337.

8) Anamet Laboratories, Inc., 3400 Investment Blvd., Hayward CA 94545.

9) T.P. Weihs, T.W. Barbee, Jr., M.A. Wall, submitted to J. Mater. Res.

10) K. Blobaum, T.P. Weihs, T.W. barbee, Jr., and M.A. Wall, this symposium.

11) T.P. Weihs, T.W. Barbee, Jr., M.A. Wall, Mat. Res. Soc. Proceedings, Vol 311, edited by M. Atzmon, A.L.Greer, J.M. Harper, and M.R. Liberia, Spring 1993.

12) O.J. Kleppa and S. Wanatabe, Metall. Trans. B, 13, 391 (1982).

13) J. Murray, A. Peruzzi, and J.P. Abriata, J. Phase Equil., 13, 277 (1992).

14) R.J. Kematick and H. F. Franzen, J. of Sol. State Chem., 54, 226 (1984).

15) S.V. Meschel and O.J. Kleppa, J. of Alloys and Comp., 191, 111 (1993). 